\title{
Papers
}

\section{Where does blood go? Prospective observational study of red cell transfusion in north England}

\author{
A W Wells, P J Mounter, C E Chapman, D Stainsby, J P Wallis
}

\begin{abstract}
Objective To collect population based information on transfusion of red blood cells.

Design Prospective observational study over 28 days. Setting Hospital blood banks in the north of England (population 2.9 million).

Main outcome measures Indications for transfusion, number of units given, and the age and sex of transfusion recipients.

Participants All patients who received a red cell transfusion during the study period. Data completed by hospital blood bank staff.

Results The destination of 9848 units was recorded (97\% of expected blood use). In total 9774 units were transfused: $5047(51.6 \%)$ units were given to medical patients, $3982(40.7 \%)$ to surgical patients, and 612 $(6.3 \%)$ to obstetric and gynaecology patients. Nearly half $(49.3 \%)$ of all blood is given to female recipients, and the mean age of recipients of individual units was 62.7 years. The most common surgical indications for transfusion were total hip replacement $(4.6 \%$ of all blood transfused) and coronary artery bypass grafting (4.1\%). Haematological disorders accounted for $15.5 \%$ of use. Overall use was 4274 units per 100000 population per year.

Conclusion In the north east of England more than half of red cell units are transfused for medical indications. Demand for red cell transfusion increases with age. With anticipated changes in the age structure of the population the demand for blood will increase by $4.9 \%$ by 2008 .
\end{abstract}

\section{Introduction}

The health service circular Better Blood Transfusion described the action required by NHS trusts and clinicians to improve quality within transfusion practice and highlighted the need for research and review of treatment with blood components. ${ }^{1}$ Information on the use of red cells and the characteristics of transfusion recipients is limited. ${ }^{2-5}$ There is no population based information on transfusion available for the United Kingdom. Collection of such data may improve the understanding of fluctuations in demand, help to predict future trends in red cell use, and define the salvage or autologous preoperative deposit. These potential value of techniques such as perioperative cell benefits will help in planning to meet challenges to the blood supply, including variant Creutzfeldt-Jakob disease.

The north of England is a geographically well defined region with a stable population of 2.9 million. The region's hospitals include three teaching hospitals and 15 district general hospitals. They deliver a full range of medical and surgical services, including bone marrow transplantation for children and adults. Cardiothoracic surgery is performed at two separate centres. There are also supraregional services for solid organ transplantation and severe combined immunodeficiency in children. The region has few patients requiring transfusion for haemoglobin disorders.

The Newcastle centre of the National Blood Service (NBS) supplies blood components to all hospital blood banks in the region. It issues over $130000 \mathrm{red}$ cell units per year, and the centre is a net exporter of blood within the blood service.

The Northern Region Haematology Group has been prospectively registering patients with acute myeloid leukaemia and other haematological malignancies for over 18 years. ${ }^{6}$ This long history of cooperation among the region's haematologists has allowed us to undertake a prospective population based survey of the indications for red cell transfusion across the region.

\section{Methods}

We obtained information from all NHS hospital blood banks served by the Newcastle centre. We collected data using a one page preprinted report form classifying the stated indication or surgical procedure for transfused red cell units. Any transfusion related to an operation, whether before, during, or after surgery, was ascribed to that procedure and speciality. Information on blood that was wasted or out of date was requested, but we made no attempt to record indications or operations for which blood was requested but not used. We also recorded the age and sex of the transfusion recipient.

We placed all transfusions for gastrointestinal bleeding, whether under the care of a surgeon or physician, in a single category as a subdivision of medical indications. Of the remaining medical transfusions, we classified haematological disorders and neonatal top-up or exchange transfusions separately.

We collected data for two 14 day periods in October 1999 and June 2000. Records from both peri-

\author{
National Blood \\ Service, Newcastle \\ Centre, Newcastle \\ upon Tyne \\ NE2 4NQ \\ A W Wells \\ specialist registrar \\ P J Mounter \\ specialist registrar \\ C E Chapman \\ consultant in \\ transfusion medicine \\ D Stainsby \\ head of clinical audit \\ Newcastle upon \\ Tyne Hospitals \\ NHS Trust, \\ Freeman Road \\ Hospital, Newcastle \\ upon Tyne \\ NE7 7DN \\ $\mathrm{J}$ P Wallis \\ consultant \\ haematologist \\ Correspondence to: \\ $\mathrm{J} P$ Wallis \\ jonathan.wallis@tth. \\ nuth.northy.nhs.uk \\ bmj.com 2002;325:803
}


Table 1 Indications for red cell transfusion

\begin{tabular}{lcc} 
& $\begin{array}{c}\text { No (\% of all transfused and } \\
\mathbf{9 5 \%} \mathbf{~ C l ) ~ o f ~ u n i t s ~} \mathbf{( n = 9 7 7 4 )}\end{array}$ & $\begin{array}{c}\text { Mean (SD) age (years) of } \\
\text { recipients }\end{array}$ \\
\hline Medicine: & $5047(51.6,50.6$ to 52.7$)$ & $64.6(19.7)$ \\
\hline All uses & $2269(23.2)$ & $67.1(17.1)$ \\
\hline Anaemia & $1514(15.5)$ & $61.2(20.5)$ \\
\hline Haematology & $1054(10.8)$ & $69.2(15.5)$ \\
\hline Gastrointestinal bleed & $148(1.5)$ & $55.5(23.0)$ \\
\hline Other & $62(0.6)$ & 0 \\
\hline Neonatal top up/exchange transfusion & $3982(40.7,39.7$ to 41.7$)$ & $64.1(18.2)$ \\
\hline Surgery & $612(6.3,5.6$ to 6.8$)$ & $38.7(18.0)$ \\
\hline Obstetrics and gynaecology: & $307(3.1)$ & $47.7(19.5)$ \\
\hline All uses & $305(3.1)$ & $29.7(10.5)$ \\
\hline Gynaecology & $133(1.4,1.1$ to 1.6$)$ & $60.5(20.14)$ \\
\hline Obstetrics & &
\end{tabular}

*67.2 (20.1) for all transfusions.

Table 2 Indications for red cell transfusion in surgical patients

\begin{tabular}{|c|c|c|}
\hline & $\begin{array}{c}\text { No (\% of all transfused and } \\
95 \% \mathrm{Cl} \text { ) of units }\end{array}$ & $\begin{array}{c}\text { Mean (SD) age (years) } \\
\text { of recipients }\end{array}$ \\
\hline \multicolumn{3}{|l|}{ Orthopaedics and trauma: } \\
\hline All & $1358(13.9,13.2$ to 14.6$)$ & $66.6(19.1)$ \\
\hline Total hip replacement & $446(4.6)$ & $68.6(13.3)$ \\
\hline Fractured neck of femur & $180(1.8)$ & $79(12.0)$ \\
\hline Total knee replacement & $161(1.6)$ & $70.9(12.4)$ \\
\hline Road traffic accident & $141(1.4)$ & $41.1(14.7)$ \\
\hline Other & $430(4.4)$ & $63.4(23.3)$ \\
\hline \multicolumn{3}{|l|}{ General surgery: } \\
\hline All & $935(9.6,9.0$ to 10.2$)$ & $62.7(18.6)$ \\
\hline Abdominal surgery (excluding colorectal) & $430(4.4)$ & $67.1(13.8)$ \\
\hline Colorectal surgery & $267(2.7)$ & $67.5(12.7)$ \\
\hline Other & $238(2.4)$ & $49.5(24.4)$ \\
\hline \multicolumn{3}{|l|}{ Cardiothoracic surgery: } \\
\hline All & $600(6.1,5.7$ to 6.6$)$ & $63.7(17.4)$ \\
\hline Coronary artery bypass grafting & $398(4.1)$ & $67.6(9.8)$ \\
\hline Other & $202(2.1)$ & $55.9(24.8)$ \\
\hline \multicolumn{3}{|l|}{ Vascular surgery: } \\
\hline All & $448(4.6,4.2$ to 5.0$)$ & $69.5(10.8)$ \\
\hline Emergency repair aortic aneurysm & $226(2.3)$ & $68.9(9.1)$ \\
\hline Other & $222(2.3)$ & $70.2(12.4)$ \\
\hline Urology & $254(2.6)$ & $66.8(12.9)$ \\
\hline Transplant & $167(1.7)$ & $43.4(13.9)$ \\
\hline Neurosurgery & $113(1.2)$ & $59.7(18.5)$ \\
\hline Ear, nose, and throat & $57(0.6)$ & $63.8(11.6)$ \\
\hline Plastic surgery & $50(0.5)$ & $46.8(25.8)$ \\
\hline
\end{tabular}

ods were collated and entered on to a computer database (Access 2000, Microsoft Corporation). We used GraphPad InStat (version 3.01) and GraphPad Prism (version 3.02) for Windows (GraphPad Software, San Diego, CA, USA) for statistical analysis. We analysed the results by units used within each category, not individual episodes of transfusion. We did not combine information from individual patients who received more than one transfusion during the study period. We obtained estimates of the region's mid-year resident population for 1998, 2003, and 2008 (based on information from the 1991 census) from the Office for National Statistics.

\section{Results}

We obtained data from all 18 NHS hospital blood banks across the region. Information from two hospitals was collected retrospectively with clerical assistance from the blood service. At a third hospital data were obtained from blood bank computer records and the hospital information service.

Information on the use of 9848 units was returned; 9774 units were recorded as transfused. Over the study periods the Newcastle centre issued 10243 to the region's hospitals and accepted 190 returned units. We did not collect data from private and military hospitals in the region; 28 units were issued to these hospitals during the study. The data therefore account for at least $97 \%$ of probable red cell use during the four weeks of the study. We cannot give a precise figure for compliance because hospital stocks may have varied between the beginning and end of the study periods.

A total of 3982 units (40.7\% of all transfused blood) were transfused for surgical indications, 5047 (51.6\%) for medical indications, and 612 (6.3\%) for obstetric or gynaecological indications (table 1). No clinical details were supplied regarding the indication for 133 transfused units (1.4\%), and 74 units were reported as wasted. Table 2 shows the distribution of blood used for surgical indications. Single surgical procedures that accounted for less than $1 \%$ of blood use are not presented separately.

\section{Demographics of recipients}

Information regarding age and sex was available for the recipients of 9537 units, 4701 of which were transfused to female patients $(49.3 \%, 95 \%$ confidence interval 48.2 to 50.4 ).

The average age of a patient receiving an individual unit of blood was 62.7 years (median 67 years, SD 20.1 years). By age 5454 units blood were transfused to patients aged 65 years and above (57.2\%), 119 units were given to children under 1 year $(1.2 \%)$, and 134 units $(1.4 \%)$ were given those aged 1 to 15 years inclusive. Figure 1 shows blood use by age and specialty.

Red cell use per 100000 population per year was 4274 units overall. By age this was 15082 units in those aged 65 years and over, and 2184 units in those aged less than 65 years. The standardised transfusion rate was 2673 units per 100000 population (calculated with world standard population). Figure 2 shows age specific rates of red cell use in greater detail.

\section{Predictions for future red cell use}

Using these figures and applying them to population predictions for 2003 and 2008 we have calculated anticipated demand for transfusion assuming age spe-

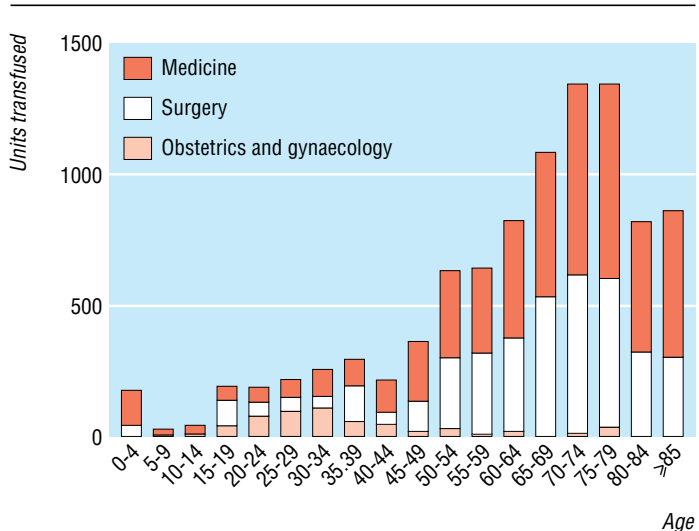

Fig 1 Blood use by age and specialty 


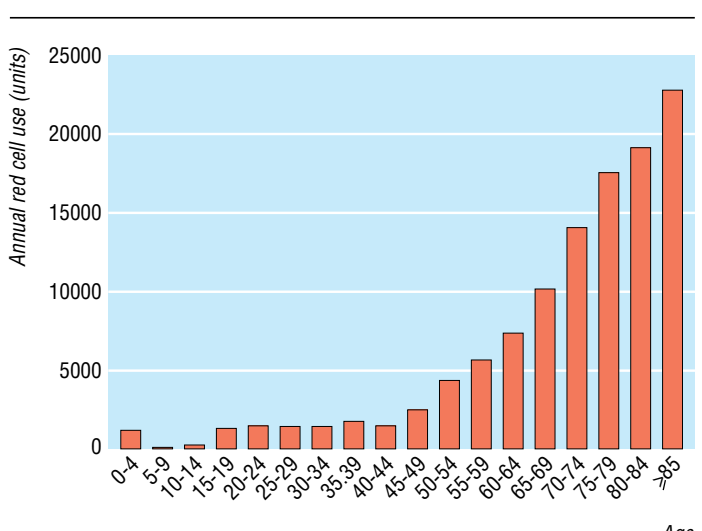

Fig 2 Age specific transfusion rates (annual red cell use per 100000 population)

cific transfusion rates remain constant (table 3). We estimate that regional demand will increase by $2.0 \%$ in 2003 and $4.9 \%$ in 2008.

\section{Comparison between study periods}

The data collected in each phase of the study (4745 units in October 1999 and 5103 units in June 2000) were similar, with mean ages of recipients of 63.3 and 62.1 years, respectively (the median age for both periods was 68 years). There was no difference in the distribution of blood between the major transfusion categories.

\section{Discussion}

In our region $52 \%$ of blood was transfused for medical indications, $41 \%$ for surgical procedures, and $6 \%$ for obstetric and gynaecological indications. Age related transfusion rates show a rapid rise above the age of 45 years with this trend continuing to 85 years and above. As a consequence small changes in the proportion of elderly people within a population will have large effects on future requirements for red cells. We predict a 5\% increase in red cell demand by 2008 .

\section{Strengths and weaknesses}

We believe our study to be unique in reporting large scale population based transfusion data in the United Kingdom. Our survey depended on the collaboration of hospital blood bank staff. Information was returned promptly, and there was high concordance with expected use of red cell on the basis of issues during the study period. This suggests we have data for almost all red cell transfusions during the study period.

The wastage figures we have collected may be incomplete. Information from the national blood stocks management project reported wastage of $2.25 \%$ in 40 NHS hospitals. ${ }^{7}$ In the United States Wallace et al reported that $9.7 \%$ of available allogeneic red cell units were wasted in $1994 .^{8}$ Their transfusion rate of 42.8 unit per 1000 population was remarkably similar to our figure. ${ }^{8}$

Our methods of data collection meant that we could not assess the total number of red cells given to any individual. Autologous red cell transfusions were not identified separately, though this is only a small part of transfusion practice as only 150 autologous units are collected by the transfusion centre each year.

Anaemia, as a subcategory of medical indications for transfusion, accounts for $23.3 \%$ of use; we did not attempt to classify this further. It is possible that some transfusions that were related to surgery will have been placed in this category by error.

\section{Comparison with other studies}

In contrast with similar surveys of red cell use we recorded lower use in surgical patients. Excluding blood use in obstetric and gynaecological surgery, Vamvakas and Taswell reported that $51.6 \%$ of red cells were transfused to surgical patients, and the French RECERT group found 49\% of transfusion recipients were on surgical wards. ${ }^{59}$ The Sanguis study documented wide variation in transfusion practice across Europe for apparently similar surgical procedures. ${ }^{10}$ Reasons for the lower surgical transfusion rate in our study could include differences in medical practice, the age profile and health status of our population, or currently evolving patterns of blood use in surgery.

Table 3 Current regional population and red cell use with estimates for 2003 and 2008

\begin{tabular}{|c|c|c|c|c|c|c|}
\hline \multirow[b]{2}{*}{ Age (years) } & \multicolumn{2}{|c|}{ 1999-2000 } & \multicolumn{2}{|c|}{2003} & \multicolumn{2}{|c|}{2008} \\
\hline & $\begin{array}{c}\text { Regional population } \\
\text { (1000s) }\end{array}$ & $\begin{array}{l}\text { Estimated annual } \\
\text { red cell use }\end{array}$ & $\begin{array}{c}\text { Estimated } \\
\text { population (1000s) }\end{array}$ & $\begin{array}{l}\text { Estimated annual } \\
\text { red cell use }\end{array}$ & $\begin{array}{c}\text { Estimated } \\
\text { population (1000s) }\end{array}$ & $\begin{array}{l}\text { Estimated annual } \\
\text { red cell use }\end{array}$ \\
\hline $0-4$ & 169.4 & 2177 & 159.3 & 2047 & 154.1 & 1980 \\
\hline $5-9$ & 189.3 & 339 & 169.3 & 303 & 159.3 & 285 \\
\hline 10-14 & 191.4 & 574 & 188.6 & 565 & 169.0 & 506 \\
\hline$\overline{15-19}$ & 187.2 & 2490 & 193.2 & 2570 & 191.6 & 2548 \\
\hline $20-24$ & 164.9 & 2451 & 183.5 & 2727 & 190.2 & 2827 \\
\hline $25-29$ & 203.1 & 2855 & 155.8 & 2190 & 170.9 & 2402 \\
\hline $30-34$ & 223.7 & 3350 & 203.0 & 3040 & 156.1 & 2338 \\
\hline $35-39$ & 221.4 & 3832 & 223.4 & 3867 & 202.9 & 3512 \\
\hline 40-44 & 200.0 & 2859 & 220.3 & 3145 & 222.6 & 3177 \\
\hline $45-49$ & 194.1 & 4745 & 197.1 & 4818 & 217.6 & 5319 \\
\hline 50-54 & 193.1 & 8356 & 190.4 & 8239 & 193.8 & 8386 \\
\hline $55-59$ & 152.2 & 8486 & 187.9 & 10477 & 185.4 & 10337 \\
\hline $60-64$ & 148.2 & 10741 & 144.9 & 10502 & 179.7 & 13025 \\
\hline $65-69$ & 140.8 & 14183 & 136.7 & 13770 & 134.8 & 13578 \\
\hline $70-74$ & 124.8 & 17468 & 121.9 & 17062 & 120.6 & 16880 \\
\hline $75-79$ & 100.3 & 17559 & 97.8 & 17121 & 98.1 & 17174 \\
\hline $80-84$ & 56.1 & 10663 & 68.8 & 13077 & 68.7 & 13058 \\
\hline$\geqslant 85$ & 49.4 & 11224 & 49.8 & 11315 & 57.7 & 13110 \\
\hline Total & 2909.4 & 124348 & 2891.7 & 126835 & 2873.1 & 130444 \\
\hline
\end{tabular}


Blood use in cardiothoracic surgery has been reported to account for nearly a fifth of blood transfused in the United States. ${ }^{11}$ However, in central Ontario Chiavetta et al found $6.2 \%$ of red cells were used for valve replacement and coronary artery bypass grafts, a figure similar to ours. ${ }^{3}$ Rates of coronary artery bypass grafting in the Northern and Yorkshire region are 530 per million population per year compared with 451 per million population for all England (figures from the NHS Northern and Yorkshire regional office).

\section{Interpretation}

Figures from the study may help in planning effective and efficient use of the available blood supply. The introduction of donor testing for variant CreutzfeldtJakob disease could have a major impact on the numbers of blood donors, with estimates that up to $50 \%$ of active donors could be lost. We can predict the effects of blood saving strategies on overall demand for red cells. For example, a $50 \%$ reduction of blood use in elective arthroplasty would reduce overall blood requirements by $2.3 \%$. Such a reduction for joint replacement has been documented by comparative audit and review of transfusion thresholds. ${ }^{12}$ However, the high use for medical indications and the disproportionate rates of transfusion for the very elderly will limit the effect of any strategy directed only at elective surgery.

The potential for blood sparing in medical patients has not been so well defined. A recent survey of patients undergoing chemotherapy has suggested that a third will require blood transfusion. ${ }^{13}$ Erythropoietin has the potential to reduce this figure, though it is unlikely to be as successful as it has been in patients with anaemia because of renal impairment.

Children are a small part of the transfusion burden in our region. Initiatives to increase safety of blood transfusions for this group would have limited implications for the service as a whole.

\section{Conclusions}

There are likely to be major changes in future blood use due to evolving surgical practice, redefined triggers for transfusion, and the public's perceptions of blood safety. While these will all tend to reduce blood use they may not be sufficient to meet the blood demands of an ageing population. Such issues may be compounded by factors that act to reduce the blood supply.

We thank the staff at hospital blood banks across the Northern region who returned data for the study; Ross Darnell, University of Newcastle statistics service; Audrey Hemsley, National Blood Service, Newcastle Centre; and Professor Steve Proctor, Dr Penny Taylor, and the members of the Northern Region Haematology Group for their pioneering work in establishing population based data collection.

Members of the Northern Region Haematology Group

M Abela, G Baird, N Browning, P J Carey, J E Chandler, C E Chapman, P Condie, M Dewar, R D Finney, J Fitzgerald, D K

\section{What is already known on this topic}

There have been no systematic population based surveys on use of red cells in the United Kingdom

Studies in France and the United States have shown that more than half of transfused red cells go to surgical patients

\section{What this study adds}

In the north of England over half of red cells are given for medical indications

Rates of red cell transfusion rise steeply with advancing age

Small increases in the number of elderly people will have large effects on demand

Goff, M J Galloway, P J Hamilton, J P Hanley, A Hendrick, J Hudson, A Iqbal, G H Jackson, F M Keenan, P J Kesteven, A L Lennard, Z Maung, P J Mounter, I Neilly, H O'Brien, S G O'Brien, S J Proctor, M M Reid, P W G Saunders, D Stainsby, G P Summerfield, P R Taylor, H N Tinegate, C W Tiplady, J P Wallis, N West, P J Williamson, A C Wood, and A Youart.

Contributors: PJM, CEC, DS, and JPW initiated and designed the study, including the data collection form. Jeni Whitehead, Audit Assistant, NBS, Newcastle, coordinated data collection and data entry. AWW analysed the data and drafted the paper with JPW. $\mathrm{JPW}$ is the guarantor.

Funding: NBS Clinical Audit department.

Competing interests: None declared.

1 NHS Executive. Better blood transfusion. Leeds: NHS Executive, 1998 (HSC 1998/224).

2 Vamvakas EC, Taswell HF. Epidemiology of blood transfusion [see comments]. Transfusion 1994;34:464-70.

3 Chiavetta JA, Herst R, Freedman J, Axcell TJ, Wall AJ, van Rooy SC. A survey of red cell use in 45 hospitals in central Ontario, Canada. Transfusion 1996;36:699-706.

4 Cook SS, Epps J. Transfusion practice in central Virginia. Transfusion 1991;31:355-60.

5 Mathoulin-Pelissier S, Salmi LR, Verret C, Demoures B. Blood transfusion in a random sample of hospitals in France. Transfusion 2000;40:1140-6.

6 Charlton BG, Taylor PR, Proctor SJ. The PACE (population-adjusted clinical epidemiology) strategy: a new approach to multi-centred clinical research. OJM 1997;90:147-51.

7 Chapman J. The national blood stocks project [abstract 216]. Br J Haematol 2001;113(suppl 1):58.

8 Wallace EL, Churchill WH, Surgenor DM, Cho GS, McGurk S. Collection and transfusion of blood and blood components in the United States, 1994 [see comments]. Transfusion 1998;38:625-36.

9 Vamvakas EC, Taswell HF. Long-term survival after blood transfusion. Transfusion 1994;34:471-7.

10 The Sanguis Study Group. Use of blood products for elective surgery in 43 European hospitals. Transfus Med 1994;4:251-68.

11 Stover EP, Siegel LC, Parks R, Levin J, Body SC, Maddi R, et al. Variability in transfusion practice for coronary artery bypass surgery persists despite national consensus guidelines: a 24-institution study. Institutions of the Multicenter Study of Perioperative Ischemia Research Group. Anesthesiology 1998;88:327-33.

12 Wallis JP, Yates B, Siddique S. Role of transfusion audit nurse [abstract 011]. Transfus Med 2000;10 (suppl 1):15.

13 Barrett-Lee PJ, Bailey NP, O'Brien ME, Wager E. Large-scale UK audit of blood transfusion requirements and anaemia in patients receiving cytotoxic chemotherapy. BrJ Cancer 2000;82:93-7.

(Accepted 23 April 2002) 